\title{
Preliminary Evaluation on the Potential Utilization of Distiller's Solubles (SLOPS) for the Culture of the Blue Tilapia (Tilapia aurea) ${ }^{1}$
}

\author{
Francisco A. Pagán-Font, Christopher Kohler and Deborah Weiler ${ }^{2}$
}

\begin{abstract}
Different triplicated treatments of slops, a rum distillation waste product, were compared with treatments of a commercial fish feed, a commercial chicken feed and an inorganic fertilizer to evaluate the potential utilization of the by-product in the cultivation of the cichlid fish Tilapia aurea. (The study was undertaken at the Agricultural Experiment Substation in Lajas and at Magueyes Island, site of the laboratory of the Department of Marine Sciences.) Research began February 8 and ended July 3, 1974 (145 days).

Thirty $9.3 \mathrm{~m}^{3}$ plastic pools served as experimental facilities.

Fish subjected to the treatments with the raw slops gained weight at a moderate rate, but they also suffered external discoloration and darkening of the body as a result of their direct filtration of the water containing in solution the dark-colored slops. Reproductive activity of the slops-fed fish might have also been affected.

The highest production was obtained with the fish feed treatment. This was followed in descending order by the fish in the chicken feed treatment, inorganic fertilizer, yeast extract from slops, other slops preparation, and the control.

Water quality indexes such as $\mathrm{pH}$, temperature, dissolved oxygen and turbidity, were monitored throughout the work. The most evident water quality indexes affected were dissolved oxygen and turbidity. Dissolved oxygen levels were reduced dramatically upon initial release of the different slops preparations. The systems recovered after several days in terms of dissolved oxygen levels. Turbidity was very high in the slops treatments. Water in the pools that had not received any of the slops preparation exhibited a greenish color, as an indication of moderate phytoplankton growth. The pH concentration remained within the desirable range $(6.5$ to 9.0$)$ for fishculture, when measured before daybreak.
\end{abstract}

\section{INTRODUCTION}

The fast-growing world population has led to a rapid increase in the demand for foods of all types. Everyday protein needs augment at a dreadful pace. Malnutrition and undernourishment are everyday subjects of discussions, conferences and symposiums dealing with the world population increase and food problems. Fulfillment of calorie and protein requirements in the diet of man is the main factor in the worldwide prevention of malnutrition and undernourishment. The dire need for high quality animal protein cannot be overemphasized. Fish is one of the major sources of that kind of protein. Through fishculture, the flow of animal protein in the form of food for mankind may be dramatically increased and accelerated.

${ }^{1}$ Manuscript submitted to Editorial Board January 16, 1979.

${ }^{2}$ Professor and Graduate Students of Marine Sciences at the Mayagüez Campus, University of Puerto Rico. 
Pressures in search of new or additional foodstuffs have directed man to pursue and evaluate wastes produced as a result of various human activities. Recycling and manipulation of many of these wastes have yielded very promising results.

In Puerto Rico, large volumes of effluents of different kinds are being released daily into the coastal waters of the island. One of these waste materials is that which results from the rum distillation process. This waste is generally referred to as "dunder," distiller's slops or "mostos". Extracts or diluted forms of the slops have been utilized in the irrigation of sugarcane fields ${ }^{3}$. Undiluted or raw slops has also been employed as fertilizer in agriculture ${ }^{4}$.

Questions have been formulated on whether this waste is in fact polluting the island's coastal waters and biota or not, and if so, to what extent. Similarly, it is felt that part of such an effluent contains certain materials which may be amenable to positive utilization by man. In Puerto Rico one of those uses might be related to fishculture. Since 1971, fishculture efforts on the island have been intensified significantly. The main difficulty encountered in the progress of local fishculture has been the fish feed situation. The problem is twofold; 1) the lack of a locally manufactured fish feed and 2) the high cost of imported fish feeds. Awareness of the problem has moved aquaculturists in the Department of Marine Sciences to design investigations within their Aquaculture Program (Fishculture Program) directed towards the evaluation of local wastes and foodstuffs, and to determine the feasibility of utilizing some of these in the manufacture of local fish feed. Slops are being tested at present as one of those materials.

Often many kinds of wastes-agricultural, domestic or industrial-may be efficiently converted in whole or in part into fish flesh, after some sort of manipulation, management or alteration of their original effluent forms. In this manner, non-utilized or potential sources of protein are transferred or converted into edible materials in the form of fish tissue.

The report deals with the results obtained during preliminary yield trials in fishculture in which slops in various forms and preparations were compared, in terms of production, to yields from treatments involving fish feed, chicken feed, inorganic fertilizer, and a control. The fish used for the study belong to the species Tilapia aurea, commonly known as St. Peter's fish or blue tilapia.

This preliminary research was intended to determine whether or not "mostos" in its raw or processed forms has any potential use in fishculture,

\footnotetext{
"Wolf, C., The utilization of distillery slops as fertilizer, Sugar News 14, 79-80, 1933; Chem. Abstr. 27, 2248, 1933.

'Innes, R. F., (The Sugar Manufacturers' Association of Jamaica Ltd.), The agricultural utilization of dunder, Int. Sugar J. 53, 99-101, 1951.
} 
either directly (in supplemental or complete feeds) or indirectly as a fertilizer to the aquatic system.

\section{MATERIALS AND METHODS}

This work was conducted in plastic pools located at the Agricultural Experiment Substation in Lajas and on Magueyes Island, La Parguera, site of the laboratory facilities of the Department of Marine Sciences.

The experimental arrangement for this work was designed to permit a comparative evaluation of the resulting levels of production of the various treatments under study. Treatment replications were set up at each plastic pools experimental unit in complete randomized designs. The experimental procedure was as follows:

There were 10 treatments. Each treatment was replicated three times. The number of fish stocked per replication or pool in every treatment was 21 (8,400 fish/acre or 21,000 fish/ha).

Treatment 1. Fish Feed: Fish receiving a commercial pelleted sinking fish feed (FF). Treatment 2. Chicken Feed: Fish receiving a commercial pelleted chicken feed (CF). Treatment 3. Inorganic fertilizer: Commercial inorganic fertilizer applied to the aquatic system (IF). Treatment 4. Slops A: Standard or raw slops from commercial rum distillery applied to aquatic system (SA). Treatment 5. Slops B: Standard or raw slops from commercial rum distillery applied to aquatic system (SB). Treatment 6. $60^{\circ}$ Brix: Concentrated slops at $60^{\circ}$ Brix applied to aquatic system $(60 \mathrm{Bx})$. Treatment 7. $40^{\circ}$ Brix: Concentrated slops at $40^{\circ}$ Brix applied to the aquatic system $(40 \mathrm{Bx})$. Treatment 8 . Yeast extract: Yeast extracted from slops applied to the aquatic system (YE). Treatment 9. Dialyzed slops: Dialyzed slops applied to the aquatic system (DS). Treatment 10. Control: Fish stocked in the aquatic system without feeding, fertilization or slops application (C).

The rates of feeding the artificial fish feeds and chicken feeds were adjusted after every sampling period. Maximum rate of feeding for both types of feed was $10 \%$, whereas the lowest rates used with the fish and chicken feeds were 2.5 and $3.0 \%$, respectively. Fish fed chicken and fish feeds received a daily ration 6 days/week.

The standard or raw slops and the yeast extract were applied initially at a concentration of approximately $1131 \mathrm{p} / \mathrm{m}$. The $40^{\circ} \mathrm{Bx}$ was applied at a rate of $745 \mathrm{p} / \mathrm{m}$ (equivalent to $3016 \mathrm{p} / \mathrm{m}$ of raw slops). The $60^{\circ} \mathrm{Bx}$ was applied at $660 \mathrm{p} / \mathrm{m}$ (equivalent to $6600 \mathrm{p} / \mathrm{m}$ of raw slops). The dialyzed slops was applied at a rate of $371 \mathrm{p} / \mathrm{m}$ at the start.

Subsequent applications of the same concentrations were added to those replications of the slops treatment, where the vertical visibility of the aquatic systems was greater than $0.5-0.6 \mathrm{~m}$ from the surface.

Inorganic fertilizer (8-8-2) was applied at a rate of $112 \mathrm{~kg} / \mathrm{ha}(100 \mathrm{lb} /$ 
acre) per application on four different occasions-at the start and after 6, 14 and 17 weeks in experiment.

Thirty $9.6-\mathrm{m}^{3}$ plastic pools (0.0025 acre) were used for the study. Each pool was filled with tapwater. The fish were checked for parasites and disease prior to stocking. None were found, but as a preventive measure the fish were treated with a solution of formalin at a concentration of 50 $\mathrm{p} / \mathrm{m}$. Water to account for evaporation was added periodically.

Oxygen determinations were made with an oxygen meter using the modified Winkler method; $\mathrm{pH}$ measurements were made with a glass electrode and a $\mathrm{pH}$ meter.

\section{MATERIALS AND METHODS}

YIELD TRIALS

The yield trials began February 8 and ended with a complete harvest on July 3, 1974, after a total of 145 days in experiment. Samples were taken on three different occasions, after 4, 8 and 12 weeks. The levels of net production obtained from each treatment in a descending order of magnitude were as follows:

Treatment

Fish feed (highest)

Chicken feed

Inorganic fertilizer

Yeast extract

$60^{\circ} \mathrm{Bx}$

$40^{\circ} \mathrm{Bx}$

Raw slops B

Raw slops A

Dialyzed slops

Control (lowest)
Total mean net production per treatment (g)

1437.4

838.7

556.7

484.0

460.4

369.8

216.2

197.8

69.7

68.6

Table 1 shows a summary of the results of each treatment tested. These data are based on the average results from three replications per treatment. The best production obtained from any of the slops treatments was that of the yeast extract. Its standing crop represented $38.8 \%$ of the amount yielded by the fishes in the fish feed treatment. Fish from the yeast extract treatment, the best slops treatment, exhibited an average daily weight gain of $0.19 \mathrm{~g}$, compared with $0.50 \mathrm{~g}$ gain from the fish in the fish feed treatment, which gave the best production of all the 10 treatments.

The results shown in table 1 tend to indicate that the blue tilapia utilizes for growth (directly or indirectly) the various solutions or slops preparations. The fact that only two applications of the slops preparations were made to the water in the pools during the whole period evidently limited the amount of these materials to be made available through 
TABLE 1.-Summary of results obtained during preliminary yield trials of six slops treatments compared with fish and chicken feed treatments, inorganic fertilizer treatment, and a control, conducted from February 8 through July 3, 1974

\begin{tabular}{|c|c|c|c|c|c|c|c|}
\hline Treatment & $\begin{array}{l}\text { Fish stocked } \\
\text { per } \\
\text { replication }\end{array}$ & $\begin{array}{l}\text { Total fish } \\
\text { stocked per } \\
\text { treatment }\end{array}$ & $\begin{array}{l}\text { Mean initial } \\
\text { weight per } \\
\text { fish }\end{array}$ & $\begin{array}{c}\text { Total } \\
\text { weight } \\
\text { harvest }\end{array}$ & $\begin{array}{l}\text { Mean fish } \\
\text { recovered }\end{array}$ & $\begin{array}{c}\text { Mean } \\
\text { weight fish } \\
\text { harvested }\end{array}$ & Survival \\
\hline & Number & Number & G & G & Number & G & $\%$ \\
\hline Fish feed & 21 & 63 & 1.83 & 1474.0 & 20 & 73.7 & 95.2 \\
\hline Chicken feed & 21 & 63 & 1.83 & 873.4 & 19 & 46.0 & 90.5 \\
\hline \multicolumn{8}{|l|}{ Inorganic } \\
\hline fertilizer & 21 & 63 & 1.70 & 589.0 & 19 & 31.0 & 90.5 \\
\hline Slops A' & 21 & 63 & 2.14 & 238.5 & 19 & 12.6 & 60.3 \\
\hline Slops B' & 21 & 63 & 1.89 & 264.1 & 19 & 13.9 & 58.7 \\
\hline $60^{\circ} \mathrm{Bx}$ & 21 & 63 & 1.68 & 494.0 & 20 & 24.7 & 95.2 \\
\hline $40^{\circ} \mathrm{Bx}$ & 21 & 63 & 1.71 & 404.0 & 20 & 20.2 & 95.2 \\
\hline \multicolumn{8}{|l|}{ Yeast } \\
\hline extract ${ }^{1}$ & 21 & 63 & 1.71 & 514.8 & 18 & 28.6 & 57.1 \\
\hline \multicolumn{8}{|l|}{ Dialyzed } \\
\hline slops & 21 & 63 & 1.83 & 102.6 & 18 & 5.7 & 85.7 \\
\hline Control & 21 & 63 & 1.82 & 105.0 & 20 & 5.3 & 95.2 \\
\hline
\end{tabular}

'Results from these treatments are based on two replications, except for the percentage of survival, which was computed on the initial total number of fish stocked in three replications. 
fertilization for use by plankton in the aquatic systems or direct utilization (ingestion) by the fish. Of the slops treatments tested, the yeast extract offered the best potential. Some of the other slops preparations also show potential. The exact contributions of all the slops treatments to the blue tilapia could not be established from the preliminary trials.

Comparison of the slops treatments (raw, yeast, dialyzed and concentrated) with the control shows that the increase in weight of the fishes in those trials ranged from 1.6 (dialyzed slops) to 605\% (yeast extract) higher than that of fishes in the control. Therefore, it may be considered that the slops treatments, especially the yeast extract, is better in terms of production of blue tilapia than the unmanaged waters. A word of caution: As it will be seen later, the desirability of raising fish in slops waters should be at this time considered questionable perhaps with the exception of the yeast extract.

Whether the direct utilization by the fish of any of the materials from the slops preparations is beneficial to the fish remains to be determined. For instance, fish exposed to the slops treatments in the raw or concentrated state exhibited within 1 week progressive darkening of their skin and flesh. Because of their filtering ability, the blue tilapia were able to filter water from their surrounding. Thus in the case of the slops treatments in which the water had acquired a dark color, the blue tilapia was equally affected. This condition might have caused a detrimental effect on the fish on a longer term basis, but it still needs further testing. In contrast, fish subjected to the yeast extract treatment appeared normal and exhibited good external conditions. No internal analysis or checks of the fish were made.

A third element worthy of mention was one observed in respect to the reproductive activity of the blue tilapia. Reproduction and spawning activity appear normal in the fishes from the fish and chicken feeds treatments and the inorganic fertilizer treatment.

The weight of the offspring recovered from those three treatments:

Treatment

Fish feed

Inorganic fertilizer

Chicken feed

Total
Weight of offspring recovered at harvest (s)

913.3

31.7

188.8

$1,419.8$

The fish from the yeast extract treatment produced $78.5 \mathrm{~g}$ of offspring. In the remainder of the treatments, offspring production was very low. None of these other offspring yields exceeded $33.3 \mathrm{~g}$. With the slops B treatment and the control, no offspring were harvested. It seems that in the latter two treatments none or insignificant reproduction occurred. 


\section{WATER QUALITY}

Dissolved concentrations, temperature and $\mathrm{pH}$ were the only water quality indexes measured during this preliminary phase. Two main periods were deemed critical in terms of the effects of the slops treatments on the water quality of the systems. The first period dealt with the first five days after the systems had received the initial applications of the various forms of slops. The second period referred to the remaining days of the experiment.

The initial applications of the slops treatments were made on February 8,1974 . The critical period, in terms of water quality, may be defined as those days from February 9 through February 16, 1974. In that period, dissolved oxygen (DO) measurements and $\mathrm{pH}$ were taken before daybreak on February 9, 14 and 16. Results are illustrated in table 2.

TABLE 2.-Dissolved oxygen and $p H$ variations after treatments

\begin{tabular}{|c|c|c|c|c|c|}
\hline \multirow{2}{*}{ Treatment } & \multirow{2}{*}{$\frac{\text { February } 9}{\text { DO }}$} & \multicolumn{2}{|c|}{ February 14} & \multicolumn{2}{|c|}{ February 16} \\
\hline & & DO & $\mathrm{pH}$ & DO & $\mathrm{pH}$ \\
\hline & $P / m$ & $P / m$ & & $P / m$ & \\
\hline Slops A & 0.43 & 0.70 & 8.4 & 2.77 & 7.7 \\
\hline Slops B & 0.40 & 0.50 & 8.5 & 1.20 & 7.6 \\
\hline $60^{\circ} \mathrm{Bx}$ & 0.38 & 0.52 & 7.6 & 0.97 & 7.4 \\
\hline $40^{\circ} \mathrm{Bx}$ & 0.40 & 0.48 & 8.4 & 1.37 & 7.0 \\
\hline Dialyzed & 3.60 & 4.70 & 8.4 & 6.37 & 7.6 \\
\hline Yeast & 0.38 & 1.43 & 8.6 & 3.90 & 7.7 \\
\hline \multicolumn{6}{|l|}{ Inorganic } \\
\hline fertilizer & 3.20 & 3.10 & 8.4 & 5.37 & 7.6 \\
\hline Fish feed & 4.40 & 4.70 & 8.6 & 6.40 & 8.1 \\
\hline Chicken feed & 4.00 & 5.27 & 8.7 & 6.43 & 7.8 \\
\hline Control & 3.90 & 5.66 & 8.7 & 6.53 & 7.6 \\
\hline
\end{tabular}

It may be seen that, after the slops applications, the dissolved oxygen concentrations in the slops treatments suffered a marked decrease. On February 9, the day after the applications were made, the three replications of the control had a mean value of $3.90 \mathrm{p} / \mathrm{m}$, compared with values as low as 0.38 to $0.43 \mathrm{p} / \mathrm{m}$ in all the slops treatments, with the exception of the dialyzed treatment in which the oxygen concentration was $3.60 \mathrm{p} /$ $\mathrm{m}$. By February 16, the oxygen regime was already recuperating. On February 21, the oxygen concentration of all the slops treatments had increased to normal levels, ranging from 3.23 to $9.47 \mathrm{p} / \mathrm{m}$, before daybreak. On the same date, the dissolved oxygen level in the control was $7.43 \mathrm{p} / \mathrm{m}$.

Dissolved oxygen determinations were carried out on a total of 27 additional sampling days. In that period, the oxygen level in the control 
ranged from 5.6 to $8.07 \mathrm{p} / \mathrm{m}$. Extreme changes in the oxygen concentrations of the slops treatments occurred during those sampling days. The concentrations fluctuated from 0.30 to $16.40 \mathrm{p} / \mathrm{m}$.

The mean concentrations of dissolved oxygen in the fish and chicken feeds treatments and the inorganic fertilizer treatment, for the same sampling days, ranged from 3.1 to $13.7 \mathrm{p} / \mathrm{m}$.

All the information presented is a good indication that the slops in its various forms, extracts or preparations affected the dissolved oxygen levels of the aquatic systems under study. Since the systems received limited quantities of the slops preparations, the dissolved oxygen regime was able to recover in part. In the yeast extract, for example, for the remaining 27 samples in which oxygen was measured, its concentration ranged from 1.4 to $8.9 \mathrm{p} / \mathrm{m}$ with a mean concentration of $6.3 \mathrm{p} / \mathrm{m}$. That level also falls within the desirable range for suitable fishculture.

The $\mathrm{pH}$ concentrations in the slops treatments, during the same period (February 9-16) did not exhibit any marked fluctuations. It ranged in all slops treatments from 7.0 to 8.5 , before daybreak, which is a suitable range for fishculture. Similar values were recorded on February 21. In short, the $\mathrm{pH}$ concentrations from all 10 treatments (slops and others) remained within the desirable range for fishculture throughout the experiment.

\section{CONCLUSIONS}

Results of this work have demonstrated that portions of the slops effluent, which is released into certain areas of the coastal waters of the island, may have a definite use in fishculture. The use may be of a direct or indirect value. Indirectly, a slops extract or preparation may serve as a fertilizer in the aquatic system, while directly it could be utilized as an additive or material in the manufacture of local fish feed.

The blue tilapia exhibited satisfactory growth in the slops treatments. Such growth was possible despite that only two applications of slops preparations were added to the systems in a period of 145 days.

The yeast extract from the slops offers the best potential of all the slops treatments evaluated.

Of all the 10 treatments, the fish feed treatment yielded the highest net production of the blue tilapia, followed by the chicken feed, inorganic fertilizer, and yeast extract. It is possible that production from the yeast extract and the dialyzed slops could be significantly increased if larger amounts of these materials were added to the systems during a given period of time.

Observable undesirable effects of the raw and concentrated slops treatment were darkening of the water in the pools and darkening of the skin and flesh of the fishes in those systems. 
It is suspected that the reproductive activity (spawning and production of offspring) of the blue tilapia might be affected, when the fish are exposed to excessive amounts of slops. This would presumably be most significant in long term fish exposure to the slops.

Dissolved oxygen levels were reduced markedly in the pools which received the raw and concentrated slops treatments. The drop in oxygen occurred the day after the initial applications of slops were made. The oxygen regime had recovered approximately 5 to 7 days after the slops applications.

\section{RESUMEN}

Varios experimentos se realizaron para estudiar la utilidad del mosto, residuo de la destilación del ron, para la alimentación del pez cíclido Tilapia aurea (Steindachner), en comparación con un alimento comercial para peces, uno comercial para pollos y un abono inorgánico. El estudio se llevó a cabo en la subestación experimental agrícola de Lajas y en la isla de Magueyes donde está ubicado el laboratorio del Departamento de Ciencias Marinas. El estudio se inició el 8 de febrero y terminó el 3 de julio de 1974.

Treinta piscinas plásticas, cada una de $9.3 \mathrm{~m}^{3}$ se usaron para la cría de los peces.

Los peces sometidos a un régimen de mosto en forma bruta aumentaron de peso moderadamente, pero a la vez sufrieron de descoloración externa y de obscurecimiento del cuerpo, como resultado de la filtración directa del mosto disuelto en el agua de las piscinas. La reproducción de los peces expuestos al mosto pudo haberse afectado.

El rendimiento más alto se obtuvo con los peces que recibieron alimento para peces. Los siguieron en orden descendente los que recibieron alimento para pollos, el abono inorgánico, un extracto de levadura proveniente del mosto, las otras preparaciones a base de mosto y el control.

Diversos índices de calidad del agua, tales como $\mathrm{pH}$, temperatura, oxígeno disuelto y turbidez se tomaron. Los más afectados fueron el oxígeno disuelto y la turbidez. Los niveles de oxígeno disuelto bajaron drásticamente tan pronto se añadieron las soluciones con mosto, pero recuperaron luego de varios días. El mosto causó gran turbidez, pero en las piscinas que no se trataron con mosto, el agua se tornó verdosa acusando un crecimiento moderado de fitoplancton. El pH permaneció dentro de los límites deseables (6.5 a 9.0) para la piscicultura, cuando éste se determinó al amanecer. 